\title{
Determinants of Cash Crop Output Volatility in Nigeria
}

\author{
Sunday Brownson ${ }^{1}$, Ini-mfon Vincent ${ }^{1} \&$ Daniel Etim $^{2}$ \\ ${ }^{1}$ Department of Agricultural Economics and Resources Management, Akwa Ibom state University, Ikot \\ Akpaden, Mkpat Enin, Akwa Ibom State, Nigeria \\ ${ }^{2}$ Department of Agricultural Economics and Extension, University of Uyo, Akwa Ibom State, Nigeria \\ Correspondence: Sunday Brownson, Department of Agricultural Economics and Resources Management, Akwa \\ Ibom state University, Ikot Akpaden, Mkpat Enin, P.M.B. 1167, Uyo, Akwa Ibom State Ibom state, Nigeria. Tel: \\ 234-803-672-8337. E-mail: sundayakpan10@yahoo.com
}

Received: May 14, 2012 Accepted: May 29, 2012 Online Published: August 8, 2012

doi:10.5539/jas.v4n9p174 URL: http://dx.doi.org/10.5539/jas.v4n9p174

\begin{abstract}
This study estimates the short run and long run cash crop output volatility equations in Nigeria. Time series data derived from FAO data base for Nigeria and publications of Central Bank of Nigeria (CBN) covering the period 1961 to 2010 were used in the study. Unit root tests conducted on the specified time series showed that all series were integrated of order one at $1 \%$ probability level. The GARCH $(1,1)$ model was used to generate the cash crop output volatility for Groundnut, Cotton seed, Cocoa Rubber and Palm oil. The short-run and long-run elasticities of cash crop output volatility with respect to the specify explanatory variables were determined using the techniques of co-integration and error correction model estimation based on Ordinary Least Squares. The empirical results revealed that the nominal inflation rate, nominal exchange rate, loan guaranteed by ACGSF to cash crop sector, harvested hectare of cash crop and import substitution policy era influenced output volatility of cotton, groundnut, cocoa, rubber and palm oil in both short and long run periods in Nigeria. The study advocated for appropriate short and long term policy packages that should focused on the moderation of the identified significant macroeconomic shifters of cash crop output volatility in the country. Also attention should be directed towards improving the quality of land allocated to cash crop sub sector. Furthermore, the long run agricultural policies embedded in the import substitution policy should be use as basis for regulating cash crop output volatility in Nigeria.
\end{abstract}

Keywords: cash crop, volatility, GARCH, exchange rate, output, Nigeria

\section{Introducation}

Despites the contribution of agricultural sector to the economic development of Nigeria, the growth in agricultural production in the country has been undulating; and mostly attributed to lopsided agricultural policies, soil infertility problems, over dependent on rain-fed agriculture, instability in macroeconomic variables and increasing food import (Federal Republic of Nigeria, 2000 and Jeter, 2004). Government realizing the significant of the agricultural sector has severally intervened to regulate activities in the sector. During the post independence era (that is period after 1960), the source of intervention was mainly through the Development Plans and annual budgets (Garba, 2000; Akpan, 2010). Development Plans and annual budgets were used by government to provide funds for support to agricultural sector in line with the import substitution policy framework of the federal government. These funds were hardly enough to support the sector's programs due to increasing corruption tendencies among government officials, institutional and policy mis-specification among others (Garba, 2000). Agricultural related programmes and policies were initiated and implemented following the continous declining role of agriculture towards promoting economic growth in the country.

The cash crop subsector was the major area of government price intervention in the pre structural adjustment period (i.e., the period before 1986). The government replaced the Regional Marketing Boards, which controlled export of cash crops prices from 1949 to 1976, with the National Commodity Board in 1977. Central machinery was evolved for the determination of the producer prices of the cash crops. This measure was adopted in the belief that by improving commodity prices periodically, farmers' incomes as well as agricultural productivity would be enhanced. This policy stance was specifically articulated in the Third National Development Plan and later enacted into law by Decree 29 of 1977 (Akanji \& Ukeje, 1995). 
Also, government has employed numbers of monetary policy measures to increase agricultural production and at the same time curb inflation. Direct monetary control techniques were employed in the pre-SAP period. In the SAP period (1986-1993), indirect monetary measures were used which included the deregulation of interest rates and increase in commercial banks among others. In the post-SAP period (1994 to date), administratively controlled measures and guided deregulation policies were adopted (Anyanwu et al., 1997). Apart from the monetary policies, the government also employed some fiscal policy measures to ensure full employment of resources in the agricultural sector. The measures include tax holidays, tariff protection, import duty relief, bans on certain food imports and the provision of credit facilities.

Despite these incentives, it is observed that several agricultural policies periods as well as programmes implemented by the federal government of Nigeria accompanied cash crop output variability (CBN, 2010). For example, the rate of cocoa output volatility decreased from $36.4 \%$ in the period $1971-1976$, fluctuating over the years to $4.20 \%$ in $1980-1985$, then increased to $61.60 \%$ in 1986-1989 (Garba, 2000). Although, sustained growth is a rare achievement, especially in the sub Saharan Africa (Malik \& Jonathan, 2009); Agénor et al., (2000) relates output volatility to policy inconsistency in developing countries. Essang (1973) and Muroi (1989) also correlate crop output volatility in Nigeria to poor policy on technology and land use Acts. In a similar way, several empirical evidences relate output volatility to inflation rate. Fountas et al., (2006); Andreou et al., (2008), and Narayan et al., (2009) found evidence of negative effect of inflation on output volatility. Also, Coulson and Robins (1985) found evidence of positive effect while Jansen (1989) reported neutral relationship between the variables. However, Akpan (2012) provided a comprehensive study on food crop output volatility behavior in different agricultural policy programme periods in Nigeria covering the period 1961 to 2009. He used GARCH $(1,1)$ model to generate respective food crop output volatility. His results revealed that Pre-Operation Feed the Nation period (1961-1976) and Structural Adjustment Programme (1986-1993) period were the most volatile sub periods for most food crop outputs in the country. Whereas, food crop outputs were most stable during the Operation Feed the Nation period (1976-1979) and Green Revolution period (1980-1985). Also, the mean food crop outputs showed progressive growth rate across the policy programme periods since 1961, and were best during the Post Structural Adjustment period (1994-2009). Jordaan et al., (2007) in South Africa, used standard error of the ARIMA process as the measure of volatility of prices of wheat and soybeans and found that volatility in the two crops was constant over time.

Surprisingly, the direct impact of agricultural policies and some key macroeconomic variables on crop output volatility in Nigeria has received limited attention in the empirical literature; in spite that increase output was among the primary goals of most past and present agricultural policies (Ukoha, 2007; Udoh \& Akpan, 2007; Akpan \& Udoh, 2009a; Akpan \& Udoh, 2009b). The knowledge of the crop output volatility relative to any agricultural policy and the working of some key macroeconomic variables under quasi market - oriented economy like Nigeria is imperative. Crop output volatility is an indispensable input to both agricultural policy makers and farmers especially on the pattern of decision making. Increase positive crop volatility could be an indication of the stimulating effect of the existing agricultural policy and or other economic policies in operation. But some economists argue that increase in output volatility could increase farmers' income risks and uncertainties due to anticipating price volatility (Young \& Shields, 1996; Ukoha, 2007). Resource allocation efficiency among farmers could be enhanced as a result of increased in output volatility in a given policy regime provided there is a guarantee minimum price for output of crops. Therefore, following the important of output volatility and its mixed correlation with other variables in the economy, the study specifically establish the statistical relationship among cash crop (cotton, groundnut, cocoa, rubber and palm oil) volatility and agricultural policy periods as well some macroeconomic variables in Nigeria.

\subsection{Measuring Cash Crop Output Volatility}

The GARCH model of the form GARCH $(p, q)_{t}$ for which $p, q=1$ was specified and used to generate volatility for cash crop outputs in Nigeria. It was found that simple GARCH $(1,1)$ process as specified in equation (2) provided a good approximation of the data generating process for Groundnut, Cotton seed, and Cocoa enterprises However, Taylor and Schwert's GARCH $(1,1)$ as specified in equation (3) was appropriate for Rubber and Palm oil enterprises. The annual cash crop output was assumed to follow a primitive first-order autoregressive (AR) (1) process as follows;

$$
\begin{gathered}
\Delta \log \left(Y_{t}\right)=\lambda_{0}+\lambda_{1} \Delta \log \left(Y_{t-1}\right)+v_{1} \\
\text { Where } v \sim \operatorname{iid}(0,1) .
\end{gathered}
$$


Where $\left(Y_{t}\right)$ is the output of cash crops (Groundnut, Cotton seed, Cocoa Rubber and Palm oil) and $v$ is the stochastic disturbance term. The general assumption is that disturbances from Equation (1) are not auto correlated. Therefore, equation 1 is the mean equation from which the GARCH process was derived as shown in equations (2) and (3).

$$
\begin{aligned}
& V_{o l_{t}}=\delta+\alpha \sum \varepsilon^{2}{ }_{t-1}+\beta \sum h_{t-1} \\
& \mathrm{Vol}_{\mathrm{t}}=\delta+\alpha \sum / \varepsilon^{2}{ }_{t-1} /+\beta \sum h_{t-1}
\end{aligned}
$$

Equation (2) shows that the conditional variance of the error term in equation (1) which is a proxy of output volatility $\left(\mathrm{Vol}_{t}\right)$ at period ' $\mathrm{t}$ ' is explained by the past shocks or square of error term (ARCH term i.e. $\left.\varepsilon_{\mathrm{t}-1}\right)$ as described in equation (1) and past variance or volatility term (the GARCH term i.e $\mathrm{h}_{\mathrm{t}-1)}$. For equation (2) and (3) to be stationary, $\delta>0, \alpha \geq 0, \beta \geq 0$ and the persistent of volatility shocks $(\alpha+\beta)$ should be less than 1 . As the sum of $\alpha$ and $\beta$ becomes close to unity, shocks become much more persistent (Bollerslev, 1986). The inclusion of the lagged conditional variances captures some sort of adaptive learning mechanism (Bollerslev 1986, Crain and Lee 1996 and Yang et al., 2001). The estimates of equation (2) and (3) were used to test the persistence of volatility in the selected cash crop in the study period.

\section{Material and Methods}

\subsection{Study Area and Data Source}

The study was conducted in Nigeria; the country is situated on the Gulf of Guinea in the sub Saharan Africa. Data used in the study were from FAO crop production database for Nigeria and publications of the Central Bank of Nigeria (CBN) and National Bureau of Statistics. The data covered the period 1961 to 2010.

\subsection{Analytical Techniques}

To investigate factors that influence cash crop output volatility in Nigeria generated in equation 1, the following empirical model was specified based on the objective of the study.

$$
\text { Vol }_{t}=\delta_{0}+\delta_{1} \text { LnEXCHANG }_{t}+\delta_{2} \text { LnINFL }_{t}+\delta_{3} \text { LnLoan }_{t}+\delta_{4} \text { LnHect }_{t}+\delta_{5} \text { Dummy }+U_{t}
$$

Where:

$V O L_{t}=$ cash crop output volatility (Groundnut, Cotton seed, Cocoa Rubber and Palm oil) generated from the GARCH models shown in equation 1 and 2.

EXCHANG $_{t}=$ nominal exchange rate of naira for dollar $(\mathrm{N} / \$)$

Loan $_{t}=$ loan guaranteed by Agricultural Credit Guarantee Scheme fund ( $\$$ m) to cash crop sub-sector. (Note from 1961 to 1977 the scheme did not exist so we used 1 during this period)

$I N F L t=$ annual inflation rate in Nigeria (\%)

Hect $=$ annual harvested hectare of respective cash crop enterprise

$D=$ dummy variable which takes the value 1 during import substitution period (1961-1985), and 0 otherwise (1986- 2010).

$U_{t}=$ stochastic error term and $U_{t} \sim$ iid $\left(0, \delta^{2} u\right)$.

We choose import substitution period (covering 1961-1985) or pre SAP period because most agricultural policies and programmes, monetary as well as fiscal policies that affect cash crop production were initiated and implemented during this era. Examples are Regional marketing Board (1946-1976); National commodity Board in 1977; Operation Feed the Nation (OFN), and Green Revolution (GR).

\section{Results and Discussion}

The estimates of the GARCH models are presented in Table 1. The time varying pattern of the cash crop output volatility was confirmed because at least one of the coefficients of the GARCH models was significant for all the 5 cash crop enterprises. 
Table 1. The GARCH model estimates for equation 2 and 3

\begin{tabular}{|c|c|c|c|c|c|}
\hline Variable & Cotton & Groundnut & Cocoa & Rubber & Palm Oil \\
\hline \multicolumn{6}{|c|}{ Mean Equation } \\
\hline Constant & $11.97(9.31)^{* * *}$ & $14.08(15.3)^{* * *}$ & $12.41(25.3)^{* * *}$ & $11.03(7.90)^{* * *}$ & $15.62(7.30)^{* * *}$ \\
\hline \multicolumn{6}{|c|}{ Conditional Variance equation } \\
\hline Constant & $0.14(1.10)$ & $0.03(1.20)$ & $0.016(0.25)$ & $0.03(3.92)^{* * *}$ & $0.008(0.72)$ \\
\hline $\mathrm{ARCH}(\alpha)$ & $0.56(1.76)^{*}$ & $0.89(2.55)^{* *}$ & $0.82(2.25)^{* *}$ & $0.91(7.74)^{* * *}$ & $0.65(7.13)^{* * *}$ \\
\hline GARCH $(\beta)$ & $0.001(1.69)^{*}$ & $0.11(2.52)^{* *}$ & $0.12(0.04)$ & $0.004(2.04)^{*}$ & $-0.24(-1.87)^{*}$ \\
\hline Persistence & 0.56 & 0.92 & 0.94 & 0.91 & 0.89 \\
\hline AIC & 98.01 & 88.44 & 27.12 & 33.31 & -37.60 \\
\hline HQC & 107.47 & 97.90 & 34.69 & 40.88 & -30.04 \\
\hline SBC & 101.59 & 92.03 & 29.99 & 36.18 & -34.73 \\
\hline Loglik & -44.01 & -39.22 & -9.56 & -12.66 & 22.80 \\
\hline
\end{tabular}

Source: Computed by authors from data analysis

The sum of $\alpha$ and $\beta$ measures the persistence of cash crop output volatility. In all the 5 cash crop enterprises the sum of $\alpha$ and $\beta$ was close to but less than unity, thus implying the persistent volatility effect of shocks on cash crop output volatility in Nigeria. The GARCH parameters were significant at various levels of probabilities for the cash crop enterprises. Exception of cocoa enterprise, the $\beta$ coefficient was significant in Groundnut, Cotton seed, Palm oil and Rubber enterprises.

\subsection{Unit Root Test for Variables Used in the Analysis}

To ascertain the stationarity of the variables specify in the model, the standard Augmented Dickey - Fuller test and ADF-GLS tests were performed. Test statistics for each variable in levels and first differences are presented in Table 2.

Table 2. Result of the unit root test for variables used in the analysis

\begin{tabular}{|c|c|c|c|c|c|c|c|c|c|c|c|c|}
\hline & \multicolumn{6}{|c|}{ Augmented Dicker Fuller Test for unit root } & \multicolumn{6}{|c|}{ ADF-GLS test for unit root } \\
\hline Logged & \multicolumn{3}{|c|}{ With Trend } & \multicolumn{3}{|c|}{ Without Trend } & \multicolumn{2}{|c|}{ With Trend } & & \multicolumn{3}{|c|}{ Without Trend } \\
\hline Variables & Level & 1st diff. & OT & Level & 1st diff. & OT & Level & 1st diff. & OT & Level & 1st diff. & OT \\
\hline VCot & -3.26 & $-6.89 *$ & 1(1) & -2.48 & $-6.97 *$ & 1(1) & -3.34 & $-7.04 *$ & $1(1)$ & -2.27 & $-7.05^{*}$ & $1(1)$ \\
\hline $\mathrm{VG} / \mathrm{N}$ & -1.91 & $-7.38^{*}$ & 1(1) & -1.45 & $-7.42 *$ & 1(1) & -2.12 & $-6.94 *$ & 1(1) & -1.29 & $-6.81 *$ & $1(1)$ \\
\hline VCocoa & -2.88 & $-7.62 *$ & 1(1) & -2.54 & $-7.70^{*}$ & 1(1) & -2.93 & $-7.71 *$ & 1(1) & -2.47 & $-7.62 *$ & 1(1) \\
\hline VRubber & -2.64 & $-6.15^{*}$ & 1(1) & -1.73 & $-6.25^{*}$ & $1(1)$ & -2.65 & $-6.06^{*}$ & $1(1)$ & -1.52 & $-6.03 *$ & 1(1) \\
\hline VOilplm & -2.49 & $-10.1 *$ & $1(1)$ & -1.24 & $-10.14 *$ & $1(1)$ & -2.47 & $-10.1 *$ & 1(1) & -1.09 & $-9.07 *$ & 1(1) \\
\hline HaCot & -2.72 & $-6.67 *$ & $1(1)$ & -2.61 & $-6.72 *$ & $1(1)$ & -2.75 & $-6.79 *$ & 1(1) & -2.05 & $-6.79 *$ & $1(1)$ \\
\hline $\mathrm{HaG} / \mathrm{N}$ & -1.09 & $-7.65^{*}$ & $1(1)$ & -1.02 & $-7.42 *$ & $1(1)$ & -1.15 & $-6.72 *$ & 1(1) & -1.03 & $-5.42 *$ & 1(1) \\
\hline HaCocoa & -0.26 & $-8.35^{*}$ & $1(1)$ & 1.52 & $-7.29^{*}$ & $1(1)$ & -0.55 & $-8.42 *$ & 1(1) & -1.51 & $-7.25^{*}$ & 1(1) \\
\hline HaRubber & -1.78 & $-4.65^{*}$ & 1(1) & -0.17 & $-4.59 *$ & $1(1)$ & -1.26 & $-4.75^{*}$ & 1(1) & -0.16 & $-4.63 *$ & $1(1)$ \\
\hline HaOilPlm & -2.19 & $-7.26^{*}$ & 1(1) & -0.69 & $-7.07^{*}$ & 1(1) & -1.70 & $-7.05^{*}$ & 1(1) & -0.79 & $-6.71 *$ & $1(1)$ \\
\hline INFL & -3.05 & $-6.89^{*}$ & $1(1$ & -2.58 & $-6.97 *$ & $1(1)$ & -3.10 & $-4.94^{*}$ & $1(1)$ & -2.52 & $-3.12 *$ & 1(1) \\
\hline Loan & -1.91 & $-6.83^{*}$ & 1(1) & -1.26 & $-6.88^{*}$ & $1(1)$ & -1.99 & $-6.94 *$ & $1(1)$ & -0.49 & $-6.92 *$ & $1(1)$ \\
\hline ExchRat & -1.89 & $-5.50 *$ & $1(1)$ & 0.57 & $-5.36^{*}$ & $1(1)$ & -1.24 & $-5.63^{*}$ & 1(1) & -1.21 & $-5.31 *$ & 1(1) \\
\hline \multicolumn{13}{|c|}{ Critical value defines at $1 \%$ level of significance } \\
\hline $1 \%$ & -4.16 & -4.17 & & -3.57 & -3.58 & & 3.77 & 3.77 & & & & \\
\hline
\end{tabular}

Note: OT means order of integration. Critical value (CV) is defined at $1 \%$ significant level and asterisk * represents $1 \%$ significance level. VCot, VG/N, VCocoa, VRubber, and VOilpalm are volatility of respective cash crops. HaCot, $\mathrm{HaG} / \mathrm{N}$, HaCocoa, HaRubber and HaOilpalm are harvested hectare of respective cash crops. Other variables are as defined in equations (4).

The test result reveals that at level, all variables (in log) used in this study were non-stationary; but stationary at first difference and are therefore integrated of order $1\{$ i.e. $1(1)\}$. We cannot therefore specify equation 4 in the 
level of the variables without the risk of obtaining spurious regression.

The existence of the cointegration between the cash crop volatility and the regressors was determined. The Engle-Granger two-step procedure was adopted to test for cointegration (Gujarati, 2004). The order of integration of the residuals generated from equation (4) for each of the 5 cash crop enterprises were evaluated and were found significant. Consequently, the existence of cointegration with respect to the regressands and regressors in each of the 5 cash crop enterprise equations (i.e. equation 4) could not be rejected. Table 3 presents the results of the long-run (static) regression, while Table 4 shows the order of integration of the residuals generated from static models.

Table 3. Cointegration or long-run equation of cash crop output volatility in Nigeria

\begin{tabular}{llllll}
\hline Variables & Cotton & Groundnut & Cocoa & Rubber & Palm oil \\
\hline Constant & $3.08(1.54)$ & $4.73(2.14) * *$ & $-4.93(3.64) * * *$ & $-4.31(-3.35)$ & $-0.35(-0.57)$ \\
LnINFL & $-0.04(-1.03)$ & $-0.03(-0.76)$ & $-0.01(-1.06)$ & $0.02(0.72)$ & $0.002(0.70)$ \\
LnExchang & $0.11(2.55)^{* *}$ & $0.29(4.56)^{* * *}$ & $-0.04(-2.02)^{* *}$ & $-0.09(-2.19)^{*}$ & $0.03(6.54)^{* * *}$ \\
LnLoan & $0.05(3.62)^{* * *}$ & $0.03(1.86)^{*}$ & $0.02(5.72)^{* * *}$ & $0.02(1.59)$ & $0.002(1.30)$ \\
LnCrop Hect & $-0.25(-1.79)^{*}$ & $-0.39(-2.55) * *$ & $0.37(3.57) * * *$ & $0.37(3.45) * * *$ & $0.02(2.46)^{* *}$ \\
Dummy & $0.47(2.42)^{* *}$ & $1.18(5.67)^{* * *}$ & $0.04(1.78) * *$ & $0.04(0.39)$ & $0.10(6.93)$ \\
$\mathrm{R}^{2}$ & 0.46 & 0.56 & 0.61 & 0.76 & 0.83 \\
F-cal & $7.14 * * *$ & $10.59 * * *$ & $13.36 * * *$ & $27.11 * * *$ & $39.82 * * *$ \\
\hline
\end{tabular}

Note: Asterisks *,** and $* * *$ represent $10 \%, 5 \%$ and $1 \%$ significance levels respectively. Variables are as defined in equation (4).

The results in Table 4 suggest that the variables in equations 4 specify for the 5 cash crop enterprises are co-integrated. The implication of the result is that an error correction specification would provide a better fit for equation 4 in all the 5 cash crop enterprises than would be the case without it.

Table 4. Engle-Granger co-integration regression test on residuals generated from Equation 4 for cash crop enterprises

\begin{tabular}{|c|c|c|c|c|c|c|c|c|c|c|c|c|}
\hline \multirow{3}{*}{$\begin{array}{l}\text { Residuals } \\
(\mathrm{ECM})\end{array}$} & \multicolumn{6}{|c|}{ ADF unit root test } & \multicolumn{6}{|c|}{ ADF-GLS unit root test } \\
\hline & \multicolumn{3}{|c|}{ With Trend } & \multicolumn{3}{|c|}{ Without Trend } & \multicolumn{3}{|c|}{ With Trend } & \multicolumn{3}{|c|}{ Without Trend } \\
\hline & Level & 1st diff. & OT & level & 1st diff. & OT & level & 1st diff. & OT & level & 1st diff. & OT \\
\hline Cotton & $-3.99 * *$ & - & $1(0)$ & $-4.02 * *$ & - & $1(0)$ & $-4.07 * *$ & - & $1(0)$ & $-3.98 * *$ & - & $1(0)$ \\
\hline Groundnut & $-4.96^{* *}$ & - & $1(0)$ & $-4.53 * *$ & - & $1(0)$ & $-4.42 * *$ & - & $1(0)$ & $-4.55 * *$ & - & $1(0)$ \\
\hline Cocoa & $-5.45 * *$ & - & $1(0)$ & $-5.52 * *$ & - & $1(0)$ & $-5.38^{* *}$ & - & $1(0)$ & $-5.50 * *$ & - & $1(0)$ \\
\hline Rubber & $-3.99 * *$ & - & $1(0)$ & $-4.09 * *$ & - & $1(0)$ & $-4.01 * *$ & - & $1(0)$ & $-3.65 * *$ & - & $1(0)$ \\
\hline Palm Oil & $-6.09 * *$ & - & $1(0)$ & $-6.14 * *$ & - & $1(0)$ & $-6.15^{* *}$ & - & $1(0)$ & $-5.86^{* *}$ & - & $1(0)$ \\
\hline $1 \% * *$ & -4.16 & & & -3.57 & & & -3.77 & & & & & \\
\hline $5 \% *$ & -3.51 & & & -2.92 & & & -3.19 & & & & & \\
\hline
\end{tabular}

Note: OT means order of integration. Critical value (CV) is defined at $1 \%\left(^{* *}\right)$ and $5 \%\left(^{*}\right)$ probability levels. Variables are as defined in equations (4).

\subsection{Selecting Optimal Lag-length for the Co-integrating Series}

To estimate the error correction model, an optimal lag length was determined for the specify variables. The 
Akaike criterion (AIC), Schwarz Bayesian criterion (SBC) and Hannan - Quinn criterion (HQC) were used to select appropriate lag length for the cointegrating series. The test results as shown in Table 5 reveal that the optimum lag length appropriate for generating a more interpretable parsimonious ECM model for the specified variables was at the first lag for Cotton seed, Groundnut, cocoa and Rubber crop volatility equation. For Palm oil the optimum lag length was at lag 2 indicated by the asterisks among the information criteria.

Table 5. Optimal lag length of variables used in each cash crop equation in the analysis

\begin{tabular}{lllllll}
\hline Equations & Lags & loglike & $\mathbf{p}(\mathbf{L R})$ & AIC & SBC & HQC \\
\hline \multirow{3}{*}{ Cotton Seed } & 1 & 12.68 & 0.00 & $-0.24^{*}$ & $0.034^{*}$ & $-0.14^{*}$ \\
& 2 & 13.32 & 0.23 & -0.23 & 0.086 & -0.11 \\
\multirow{2}{*}{ Groundnut } & 1 & 3.96 & 0.00 & $0.13^{*}$ & $0.42^{*}$ & $0.24^{*}$ \\
& 2 & 4.41 & 0.34 & 0.16 & 0.48 & 0.28 \\
Cocoa & 1 & 66.65 & 0.00 & $-2.59 *$ & $-2.32 *$ & $-2.49^{*}$ \\
& 2 & 66.93 & 0.46 & -2.56 & -2.24 & -2.44 \\
Rubber & 1 & 34.36 & 0.00 & $-1.19 *$ & $-0.91 *$ & $-1.09 *$ \\
& 2 & 34.78 & 0.36 & -1.16 & -0.85 & -1.05 \\
Oil Palm & 1 & 124.22 & 0.00 & -5.09 & -4.82 & -4.99 \\
\hline
\end{tabular}

Note: Asterisk means optimum lag length of series in each cash crop volatility equation.

\subsection{Error Correction Model for Cash Crop Volatility in Nigeria}

Following the Granger Representation Theorem, we specify the ECM model for the cointegrating series in the study. The primary reason for estimating the ECM model was to capture the dynamics in the cash crop output volatility equations in Nigeria in the short-run and identify the speed of adjustment as a response to departure from the long-run equilibrium. The general specification of the ECM that was estimated for the cash crop output volatility in Nigeria is shown below:

$$
\begin{gathered}
\Delta \mathrm{Vol}_{\mathrm{t}}=\delta_{0}+\delta_{1} \Delta \mathrm{LnVol}_{\mathrm{t}-1}+\delta_{2} \Delta \mathrm{LnEXCHANG}_{\mathrm{t}-2}+\delta_{3} \Delta \mathrm{LnINFL}_{\mathrm{t}-2}+\delta_{4} \Delta \mathrm{LnLoan}_{\mathrm{t}-2}+\delta_{5} \Delta \mathrm{LnHect}_{\mathrm{t}-2}+\delta_{6} \text { Dummy }^{+} \\
\delta_{7} \mathrm{ECM}_{\mathrm{t}-1}+\mathrm{U}_{\mathrm{t}}
\end{gathered}
$$

The variables are as defined previously in equation (4). To obtain a parsimonious dynamic ECM for the cash crop output volatility in Nigeria, the study adopted Hendry's (1995) approach in which an over parameterized ECM model was initially estimated and then gradually reduced by eliminating insignificant lag variables until a more interpretable and parsimonious ECM model was obtained. The result of the exercise is presented in Table 6.

The results revealed that coefficients of the error correction term (ECM) was negative and statistically significant at $1 \%, 5 \%, 1 \%, 1 \%$ and $1 \%$ probability levels for Cotton seed, Groundnut, Cocoa, Rubber and Oil Palm equation respectively. The results validate the existence of a long-run equilibrium relationship among the time series in each of the cash crop volatility equation, and also indicate that the cash crop volatility in Nigeria is sensitive to the departure from it equilibrium value in the previous periods. The negative sign implies that, in the absence of variation in the independent variables, the model's deviation from the long run relation is corrected by increase in the dependant variable. For instance, the estimated coefficient of the $E C M_{t-1}$ is -0.92 for Cocoa suggesting that in the absence of changes in the explanatory variables, the deviation of the model from the long-term path is balanced by 92 per cent increased in Cocoa output volatility per year. The diagnostic tests for the ECM model for each crop enterprise indicate satisfactory results. This implies that the specified explanatory variables are important determinants of cash crop output volatility in the country. The information criteria, RESET test and the normality tests for each cash crop enterprise confirm the correctness of Ordinary Least Squares estimation technique. 
Table 6. ECM estimates of cash crop output volatility Equation in Nigeria

\begin{tabular}{|c|c|c|c|c|c|}
\hline Variables & Cotton & Groundnut & Cocoa & Rubber & Palm Oil \\
\hline Constant & $0.04(0.90)$ & $0.17(2.74)^{* * * *}$ & $-0.004(-0.28)$ & $0.02(0.55)$ & $0.01(2.28) * *$ \\
\hline$\Delta$ LnVol $_{t-1}$ & $0.12(0.90)$ & $-0.23(-1.36)$ & $0.24(1.78)^{*}$ & $0.25(1.80)^{*}$ & $-0.13(-0.89)$ \\
\hline$\triangle \operatorname{LnINFL}_{t}$ & $-0.05(-1.50)$ & $0.008(0.22)$ & - & $0.007(0.31)$ & - \\
\hline$\Delta \operatorname{LnINFL}_{t-1}$ & - & $-0.006(-0.18)$ & $0.002(0.19)$ & - & $0.006(1.91)^{*}$ \\
\hline$\Delta \operatorname{LnINFL}_{t-2}$ & - & - & - & - & $-0.002(-0.81)$ \\
\hline$\Delta \operatorname{LnExch}_{t}$ & - & $-0.07(-0.56)$ & - & $-0.001(-0.01)$ & $-0.006(-0.71)$ \\
\hline$\Delta \operatorname{LnExch}_{t-1}$ & $-0.15(-1.96)^{*}$ & $-0.30(-2.36)^{* *}$ & $-0.03(-2.71) * * *$ & - & $-0.006(-0.68)$ \\
\hline$\Delta \operatorname{LnExch}_{t-2}$ & - & - & - & - & - \\
\hline$\Delta \operatorname{LnLoan}_{t}$ & - & $-0.004(-0.14)$ & $0.009(1.74)^{*}$ & $-0.001(-0.06)$ & $0.001(0.64)$ \\
\hline$\Delta \operatorname{LnLoan}_{t-1}$ & $-0.03(-1.94)^{*}$ & $-0.08(-3.14) * * *$ & $0.005(0.69)$ & - & - \\
\hline$\Delta \operatorname{Loan}_{t-2}$ & - & - & - & - & $-0.003(-2.28)^{*}$ \\
\hline$\triangle \mathrm{LnCropHec}_{t}$ & $-0.39(-2.83)^{* * *}$ & $-0.56(2.93) * * *$ & $0.42(2.01)^{* *}$ & $-0.05(-4.31)^{* * * *}$ & $0.059(1.35)$ \\
\hline$\Delta L n C r o p H e c_{t-1}$ & $0.02(0.16)$ & $-0.57(-3.48) * * *$ & - & - & $-0.131(-3.12)^{* * * *}$ \\
\hline$\Delta L n$ CropHec $_{t-2}$ & - & - & - & - & - \\
\hline Dummy & $0.012(-0.21)$ & $-0.15(-1.91)^{*}$ & $-0.0002(-0.01)$ & $-0.015(-0.35)$ & $-0.0011(-1.78)^{*}$ \\
\hline$E C M_{t-1}$ & $-0.56(-4.48) * * *$ & $-0.42(-2.46) * *$ & $-0.92(-4.32)^{* * *}$ & $-0.67(-4.61)^{* * * *}$ & $-0.55(-3.54) * * *$ \\
\hline$R^{2}$ & 0.52 & 0.53 & 0.45 & 0.37 & 0.69 \\
\hline Adjusted $R^{2}$ & 0.42 & 0.37 & 0.33 & 0.26 & 0.53 \\
\hline$F$-cal & $5.08 * * *$ & $3.41 * * *$ & $3.76 * * *$ & $3.23 * *$ & $4.31 * * *$ \\
\hline DW-stat & 1.99 & 1.98 & 2.01 & 2.15 & 1.99 \\
\hline Log-Likelihood & 19.81 & 16.11 & 78.18 & 36.73 & 139.84 \\
\hline Hannan-Quinn & -15.45 & 0.008 & -118.19 & -51.98 & -233.23 \\
\hline Schwarz C. & -5.16 & 13.73 & -107.89 & -42.83 & -215.10 \\
\hline Akaike $C$. & -21.61 & -8.21 & -124.35 & -57.46 & -244.00 \\
\hline RESET test & $11.04(0.00)^{* * *}$ & $2.88(0.09) *$ & $12.43(0.00) * * *$ & $4.13(0.05)^{* * *}$ & $1.80(0.19)$ \\
\hline Normality test & $4.49(0.11)$ & $11.10(0.00)^{* * * *}$ & $1.03(0.59)$ & $1.78(0.41)$ & $6.18(0.05)^{* * *}$ \\
\hline
\end{tabular}

Note: Asterisks $* * *$ and $* * *$ represent $10 \%, 5 \%$ and $1 \%$ significance levels respectively. Variables are as defined in equation (5).

For Cotton Enterprise: The empirical results showed that the nominal exchange rate $\left(\mathrm{EXCH}_{\mathrm{t}}\right)$ and the value of loan guaranteed by ACGSF to cash crop sub-sector had significant negative relationship with the cotton output volatility in the short run. However in the long run, the variables had significant positive effect on cotton output volatility. Also, the slope coefficient of harvested area of cotton adversely influenced Cotton output volatility in both short and long run periods. One of the possible reasons for the result is the effect of population pressure and increased in urbanization on plantation crops. Most Cotton plantation estates in the country were encroached by human activities which lead to the relegation of the crop to area of marginal production. On the other hand, the coefficient of import substitution period (Dummy) exerted a significant positive impact on Cotton output volatility in the long run. This means that Cotton output volatility increases during period of import substitution in Nigeria.

For Groundnut Enterprise: The ECM model reveals that the nominal exchange rate, loan guaranteed by ACGSF to cash crop sub sector, harvested hectare of groundnut and pre-SAP policies are significant negative determinants of groundnut output volatility in the short run in Nigeria. The result implies that, in the short run period increased in these variables reduce the tendency of increase groundnut output volatility in the country. The result could probably be explained by the activities of marketing board that was responsible for buying groundnut from farmers and selling same to foreign merchants. Conversely, in the cointegration model the impact of nominal exchange rate, loan guaranteed by ACGSF to cash crop sub sector and harvested hectare of groundnut as well as pre-SAP policies on groundnut output volatility were significant and positive. We believe that the result is associated with the increase in domestic utilization and favorable tariff rate regime on groundnut and its derivatives that was imported into the country.

For Cocoa Enterprise: The result from the ECM model reveals that the lag coefficient of cocoa output volatility is positive and statistically significant. This indicates that the past period of cocoa output volatility affects the 
current period volatility. This is consistent with the ARCH model by Engle and Watson (1981), which postulates that volatility in the current period is related to its value in the previous period. The result also reveals that the increase in the nominal exchange rate in both short and long run models reduces cocoa output volatility in the country. Contrary, the coefficient of loan guaranteed by ACGSF to cash crop sub-sector stimulated output volatility of cocoa in both periods respectively. Similar results were obtained for harvested area of cocoa. The coefficient of import substitution variables had a positive correlation with cocoa output volatility in the long run. This implies that cocoa output volatility in the long run increases significantly during period of import substitution in Nigeria.

For Rubber Enterprise: The ECM estimates reveal that the coefficient of harvested hectare of rubber was a negative determinant of rubber output volatility. In the long run model, volatility of rubber had an inelastic significant negative relationship with respect to the nominal exchange rate and inelastic significant positive effect with respect to harvested hectare of rubber. It appears that harvested hectare of rubber is the major determinants of rubber output volatility in Nigeria.

For Palm Oil Enterprise: The coefficient of loan guaranteed by ACGSF, harvested hectare of Palm Oil and pre-SAP policy period are negative and statistically significant in the short run indicating that Palm Oil volatility decreases during period of import substitution in the country. The result in addition, reveals that inflation rate positively shifted the Palm Oil output volatility in the short run. This implies that increases in inflation rate lead to increase in Palm Oil output volatility in the short run. This could be due to increase in domestic demand as a result of decrease in the price of domestic palm oil in expense to foreign substitutes. However in the long run, the Palm Oil output volatility varies directly with the nominal exchange rate and harvested hectare of Palm Oil in the country.

\section{Conclusion}

The study identifies significant factors that influence cash crop output volatility in Nigeria. The major cash crops consider were; cotton seed, groundnut, cocoa, rubber and Palm oil. Time series data derive from FAO data base for Nigeria and publications of CBN as well as National Bureau of Statistics covering the period 1961 to 2010 were used in the study. Unit root on the specified variables confirm the presence of co-integration among the series implying the presence of a long-run equilibrium relationship. The long run and ECM models for the cash crop output volatility were estimated using the specified variables. The error term from the ECM model for each of the cash crop enterprise equation had the appropriate negative sign and was statistically significant at various probability levels indicating a quick convergence to equilibrium in each period, with intermediate adjustments captured by the differenced terms. The findings show that the inflation rate, nominal exchange rate of naira for dollar, harvested hectare of cash crops and loan guaranteed by ACGSF to cash crop sector as well as the agricultural policy content of import substitution period interact in each period to re-establish the long-run equilibrium in cash crop output volatility following a short-run random disturbance in the individual cash crop output volatility equation in the Nigeria's economy. The empirical results derived following the estimation of the long run and short run cash crop output volatility equations in Nigeria reveal mixed and inconsistence impacts of explanatory variables on cash crop output volatility in the country. It also seems that harvested hectare of cash crop is the major determinant of output volatility among cash crops in Nigeria. Following the results of the study, we recommend that government should formulates appropriate short and long term policy packages that should focused on the moderation of the identified significant macroeconomic shifters of cash crop output volatility in the Nigeria's economy. Government should strengthen the institutional framework responsible for disbursement of credit to cash crop sub-sector in the country. Also attention should be directed towards improving the quality of land allocated to cash crop sub-sector by adopting appropriate soil management technique. Furthermore, in the long run, agricultural policies embedded in the import substitution policy framework should be the basis for regulating cash crop output volatility in the country.

\section{References}

Agenor, P. R., McDermott, C. J., \& Prasad, E. S. (2000). Macroeconomic fluctuations in developing countries: some stylized facts. World Bank Economic Review, 14(2), 251-285.

Akanji, O. O., \& Ukeje, E. U. (1995). A review and analysis of agricultural prices in Nigeria. Economic and Financial Review, 33(1), 35-61.

Akpan, S. B. (2012). Analysis of food crop output volatility in Agricultural policy programme regimes in Nigeria. Developing Country Studies, 2(1), 28-35.

Akpan, S. B. (2010). Encouraging Youth Involvement in Agricultural Production and Processing in Nigeria. 
Policy Note No. 29: International Food Policy Research Institute, Washington, D. C.

Akpan, S. B., \& Udoh, E. J. (2009a). Relative Price Variability and Inflation in grain sub-sector in Nigeria. Global Journal of Agricultural Sciences, 8(2), 147-151.

Akpan, S. B., \& Udoh, E. J. (2009b). Estimating Grain Relative Price Variability and Inflation Rate Movement in Different Agricultural Policy Regimes in Nigeria. Humanity and Social Sciences Journal, 4(2), 107-113.

Andreou, E., Pelloni, A., \& Sensier, M. (2008). Is volatility good for growth? Evidence from the G7. Centre for Growth and Business Cycle Research, Discussion Paper Series No. 97, University of Manchester.

Anyanwu, J. C., Oyefusi, A., Oaikhenan, H., \& Dimowo, F. A. (1997). The Structure of the Nigerian Economy (1960-1997). Onitsha Joanee Educational Publisher.

Bollerslev, T. (1986). Generalized Autoregressive Conditional Hetroscedasticity. Journal of Econometrics, 31, 307-327.

Central Bank of Nigeria. (2010). Statistical Bulletin Central Bank of Nigeria.

Coulson, E., \& Robins, R. (1985). Aggregate economic activity and the variance of inflation: another look. Economics Letters, 17, 71-75.

Crains, S. J., \& Lee, J. H. (1996). Volatility in Wheat spot and future Markets, 1950-1993: government farm program, seasonality and causality. Journal of finance, 51, 325-343.

Engle, R. F., \& Watson, M. W. (1981). A One-factor Multivariate Time Series Model of Metropolitan Wage Rates. Journal of the American Statistical Association, 76, 774-781.

Essang, S. M. (1973). The 'Land Surplus' Notion and Nigerian agricultural development policy.

Federal Republic of Nigeria. (2000). Obasanjo's Economic Direction 1995-2003. Office of the Honourable Minister for Economic Matters, Abuja, Nigeria.

Fountas, S., Karanasos, M., \& Kim, J. (2006). Inflation uncertainty, output growth uncertainty, and macroeconomic performance. Oxford Bulletin of Economics and Statistics, 68, 319-343.

Garba, P. K. (2000). An analysis of the implementation and stability of Nigerian agricultural policies, 1970-1993. AERC Research Paper 101 African Economic Research Consortium, Nairobi.

Gujarati, D. N. (2004). Basic Econometrics. Tata McGraw-Hill publishing company limited. New Delhi, India.

Hendry, D. F. (1995). Dynamic Econometrics, Oxford: Oxford University Press.

Jansen, D. (1989). Does inflation uncertainty affects output growth? Further evidence, Federal Reserve Bank of St. Louis Review, 71, $43-54$.

Jeter, H. F. (2004). How to revive Nigeria's agricultural sector. The vanguard Lagos. Retrieved on 22 nd July2004 from http://africa.com/stories/200403040476.html

Jordaan, H., Grové, B., Jooste, A., \& Alemu, Z. G. (2007). Measuring the Price Volatility of Certain Field Crops in South Africa using the ARCH/GARCH Approach. Agrekon, 46(3).

Malik, A., \& Jonathan, R. W. (2009). The Geography of Output Volatility. Journal of Dev. Econs., 90(2), 163-178.

Muroi, Y. (1989). Economic crisis and development policies in African states in 1980s. Institute of Developing Economies (I.D. E.), Tokyo.

Narayan, P. K., Narayan, S., \& Smyth, R. (2009). Understanding the inflation-output nexus for China. China Economic Review, 20, 82-90.

Udoh, E. J., \& Akpan, S. B. (2007). Estimating Exportable Tree Crop Relative Price Variability and Inflation Movement under Different Policy Regimes in Nigeria. European Journal of Social Science, 5(2), 17-26.

Ukoha, O. O. (2007). Relative Price Variability and Inflation: Evidence from the Agricultural Sector in Nigeria. AERC Research Paper 171 African Economic Research Consortium, Nairobi.

Yang. J., Besslev, D. A., \& Leatham, D. J. (2001). Asset storability and price discovery of commodity futures markets: a new look. Journal of Future Markets, 21, 279-300.

Young, E., \& Shields, D. A. (1996). OVERVIEW: FAIR Act frames farm policy for 7 years. Agricultural outlook (USDA), April 1-4. 